\title{
ETHICAL ASPECTS OF FOOD SUPPLEMENTS IN EU AND ROMANIA
}

\author{
EMILIA STANCU ${ }^{1}$, ADRIANA-ELENA TĂEREL ${ }^{1 *}$, VALENTINA SOROCEANU $^{1}$, CRISTINA $^{2}$ \\ RAIS $^{1}$, MANUELA GHICA ${ }^{2}$
}

"Carol Davila" University of Medicine and Pharmacy, Faculty of Pharmacy, 6 Traian Vuia Street, 020956, Bucharest, Romania

${ }^{I}$ Department of Pharmaceutical Management and Marketing

${ }^{2}$ Department of Biostatistics

*corresponding author: adriana.taerel@yahoo.com

Manuscript received: January 2019

\begin{abstract}
Food supplements represent a complex domain, with controversial ethical aspects and different peculiarities in Europe compared to the US. These products are of two types - with vitamins and minerals and with nutritional or physiological substances - each having its own approach. The paper is structured into two parts, the first being dedicated to the presentation of European and national legislation, with reporting of some ethical issues. We noted the achievement of an own food supplements legislative framework, clearly separated from that of medicines and foods. In the second part of the paper are presented the results of a survey that we conducted in May 2018 about using the food supplements in medical practice. There were selected two groups of respondents: physicians and pharmacists (97) and consumers/patients (99) to whom it has been distributed a questionnaire with 5 questions.
\end{abstract}

\section{Rezumat}

Suplimentele alimentare constituie un domeniu complex, cu aspecte etice controversate şi particularităţi diferite în Europa faţă de SUA. Aceste produse sunt de două tipuri - cu vitamine şi minerale şi cu substanţe cu efect nutriţional sau fiziologic fiecare beneficiind de o abordare proprie. Lucrarea este structurată în două părţi, prima fiind alocată prezentării legislaţiei europene şi naţionale, cu semnalarea unora dintre problemele etice. Am constatat realizarea la nivel european a unui cadru legislativ propriu suplimentelor alimentare, clar separat de cel al medicamentelor şi alimentelor. Legislaţia din România urmează modelul european. În a doua parte a lucrării, sunt redate rezultatele unui sondaj de opinie pe care 1-am efectuat în luna mai 2018, despre utilizarea suplimentelor alimentare în practica medicală. Au fost alese două categorii de respondenţi: medici şi farmacişti (97) şi consumatori/pacienţi (99) cărora le-au fost distribuite chestionare cu câte 5 întrebări.

Keywords: ethics, food supplements, legislation, survey

\section{Introduction}

Although food supplements market in Europe presents a less permissive specific comparative to the U.S., global consumption of these products is increasing [17]. It should be emphasized that the role of food supplements is not to treat, but to complete normal diet in order to maintain the health or to improve the biological performance under demanding conditions for the body. Products reunited in the group of food supplement contain vegetal and animal substances or their mixture with various minerals, vitamins and other micro and macro nutrients.

Unlike the model adopted by the U.S., Europe food supplements are approached independently from drugs and they were found under food legislation until 2002. The strict legal framework that operates on medicines is not found in food supplements market [14].

By European Directive 2002/46/EC, a proper legislative framework started to shape for food supplements, achieving a separate regulation from food $[1,9,19]$. Thus, first steps have been made in the complex and controversial domain of the food supplements. Without restricting the free movement of these products, the aims of the Directive were to ensure consumer protection by recommending a clear legal framework for the producers of food supplements for human use. This Directive was ratified in the EU member states and became operational for Europe from 1 August 2005. It refers to the group of vitamin and mineral supplements, specifying also the opportunity for enrichment foods with these micronutrients. Lists of the minerals and vitamins admitted were drawn up. A scientific determination of dose, the setting of minimum and maximum levels according to the consumer group and the classification of micronutrients in a risk category was also proposed [22, 23].

The criteria of purity for the raw materials were defined and also the conditions to be met in the labelling and advertising of these supplements $[5,10]$. In order to encourage the evaluation at European level, the compulsoriness of notification (approval) for these products was imposed by the competent authorities of the member countries. In the paragraph 8 of article 4 of the Directive 2002/46/EC, the European Parliament 
FARMACIA, 2019, Vol. 67, 4

marked as next step the preparation of some studies and reports. On this basis it would be appreciated the opportunity to extend rules also to another type of supplements: those containing others substances with nutritional or physiological effect [17, 27, 28]. Similar as value but different as structure, the market of supplements with vitamins and minerals differs from that of the supplements with other substances. While the first shows a relative homogeneity in the whole $\mathrm{EU}$, the second is characterized by a high variability that comes from the diversity of compounds, as well as from their different use in one country to another [17]. The teams involved in the surveillance of this type of supplements' market had difficulties because of the diversity of substances and because of the various distribution channels (retail): pharmacies, "herb stores", "drug stores", "health stores", supermarkets, "face to face" sales, "on-line" orders, etc. that hampered the task of obtaining information [16]. The over 400 substances that are found in food supplements, other than vitamins and minerals, were classified into 6 groups [15, 28]: (1) essential and nonessential aminoacids: arginine, glycine, serine, leucine; (2) enzymes: amylase, invertase, lipase; (3) prebiotics and probiotics: Lactobacillus acidophilus and Bifidobacterium; (4) essential fatty acids: $\gamma$ linoleic acid, fish oil (DHA/ EPA); (5) botanical products: Panax ginseng, Ginkgo biloba, Allium sativum; and (6) other substances: coenzyme Q10, chitosan, spirulina, lycopene, lutein. Taking into account these differences, the attempt of standardization the legislation was considered inappropriate by the European Council. It has been recommended the procedure of mutual recognition, which ensures a balance between internal demand of each state and its own requirements, without bringing prejudice to the free movement on the Community market. The position taken by the European decision makers can be explained by the difficulties appeared in the implementation of some rigid or excessive regulations that are difficult to put into practice and requires further corrections. The Directive 2001/83/EC [18] imposed restrictive criteria for codification and authorization of medicinal products for human use. So, a series of concrete situations were generated and that forced the European legislative to adopt new directives, 2004/24/EC and 2004/27/EC, which made some amendments.

\section{Directive 2004/24/CE}

Prolonged use of some medicines in traditional therapy, particularly the herbal ones, led producers to request that this feature is considered a proof of effectiveness. Because of the procedure laid down by Directive 2001/83/EC, the authorization was difficult or even impossible, drug therapy being deprived of several traditional products. There were reported cases of discrimination and distortion that damage their free movement. This has led to the implementation of the Directive 2004/24/EC [1, 9, 20] which amends aspects of traditional herbal medicines. The main change made to Directive 2001/83/EC was the acceptance of simplified authorization procedure for products existing in medical use at least 30 years, from which 15 in the European Community. In order to establish the methodology and practical ways for simplified authorization, it was ordered the establishment of the EMA (European Medicines Agency) and of the HMPC (Herbal Medicinal Products Committee) [1, 9, 29, 30]. Directive 2004/27/EC

In addition to those mentioned, the application of Directive 2001/83/EC generated another problem: the one of "borderline" ("borderline issues") that could be classified both as drugs and dietary supplements. Because of this possibility of arbitrary placement under legal regulations governing two different sectors, European Court of Justice was faced with solving litigations on products that were listed as drugs in some of EU countries and as food supplements in others [28]. One of the objectives of Directive 2004/27/EC was to solve this aspect [21].

The legislation of food supplements in Romania

The market of food supplements has continuously developed in Romania with new indigenous and imported products due to an offensive strategy [5]. Following the model submitted at European level, in our country the field of food supplements is treated separately from that of drugs, with a differential regulation for the two categories of supplements. By Order 1069/2007 of the Health Ministry there had been settled rules on vitamins and mineral supplements [26]. Supplements with other substances are approached/ approved by Orders 244/2005 and 63/2006 [24, 25]. The main stages provided in these legislation documents about the management-marketing process are mentioned further.

Table I

Regulations and steps on marketing food supplements in Romania

\begin{tabular}{|l|l|l|}
\hline & \multicolumn{1}{|c|}{$\begin{array}{c}\text { Vitamin and mineral Dietary Supplements } \\
\text { (Ord 1069/2007) }\end{array}$} & $\begin{array}{l}\text { Food supplements with other substances } \\
\text { (Ord 244/2005 and Ord 63/2006) }\end{array}$ \\
\hline $\begin{array}{l}\text { Presentation } \\
\text { of products }\end{array}$ & $\begin{array}{l}\text { - vitamins and minerals listed in Annex I as chemical form } \\
\text { provided in Annex II (Article 4, paragraph 1); } \\
\text { - amounts vary between a minimum and a maximum, scientifically } \\
\text { established according to recommended daily allowance (RDA) } \\
\text { and population reference intakes (art. 5 paragraphs 1, 2, 3); } \\
\text { - expression of amounts is done as a value or as a percentage } \\
\text { (Article 8). }\end{array}$ & $\begin{array}{l}\text { - vegetal and animal extracts, } \\
\text { microorganisms, amino acids, fatty acids, bee } \\
\text { products associated or not with vitamins and } \\
\text { minerals (Article 2) }\end{array}$ \\
- only oral pharmaceutical forms (Article 3) \\
\hline
\end{tabular}


FARMACIA, 2019, Vol. 67, 4

\begin{tabular}{|l|l|l|}
\hline \hline & \multicolumn{1}{|c|}{$\begin{array}{c}\text { Vitamin and mineral Dietary Supplements } \\
\text { (Ord 1069/2007) }\end{array}$} & $\begin{array}{l}\text { Food supplements with other substances } \\
\text { (Ord 244/2005 and Ord 63/2006) }\end{array}$ \\
\hline Notification & $\begin{array}{l}\text { - by Public Health Authority from Ministry of Health (Article } \\
10 \text { paragraph 1) } \\
\text { - based on a notification file and a pattern label with the } \\
\text { registration of notification within 48 hours (Article 10 } \\
\text { paragraph 1 and Article 11) } \\
\text { - notified supplements list is published on the Ministry of } \\
\text { Health website (Article 13 paragraph 2) } \\
\text { Institute of Public Health Cluj, Iaşi, } \\
\text { Timişoara, Romania (Article 11) } \\
\text { - on the basis of a dossier with granting the } \\
\text { certificate of notification within 10 days } \\
\text { (Article 12 paragraph 2) } \\
\text { - notified supplements list is published on the } \\
\text { IFB website (Article 13 paragraph 3) }\end{array}$ \\
\hline $\begin{array}{l}\text { Labelling and } \\
\text { advertising }\end{array}$ & $\begin{array}{l}\text { - labelling is in accordance with the stipulation relating to food products } \\
\text { - the label for vitamin and mineral supplements is approved by the Public Health Authority from Ministry of } \\
\text { Health (Article 10 paragraph 1) } \\
- \text { label must be in Romanian language and must indicate name or category of nutrients, RDA, warning not to } \\
\text { exceed the RDA, warning not to abandon a normal diet, warning to store in places out of the children reach } \\
\text { - through advertising is not permitted to attribute qualities of prevention, treatment or cure }\end{array}$ \\
\hline $\begin{array}{l}\text { Supervision } \\
\text { and quality } \\
\text { control }\end{array}$ & $\begin{array}{l}\text { - by Inspection of State Sanitary from the Ministry of Health } \\
\text { (Article 15) }\end{array}$ & $\begin{array}{l}\text { - by Ministry of Health, Ministry of } \\
\text { Agriculture and Rural Development, National } \\
\text { Authority for Veterinary Health and Food } \\
\text { Safety, National Authority for Consumer } \\
\text { Protection (Article 14 paragraph 1) }\end{array}$ \\
\hline
\end{tabular}

\section{Materials and Methods}

There were studied some ethical issues regarding the use of food supplements in Romanian in current medical practice by probing the opinion of specialists and consumers/patients based on questionnaires. Questions were addressed in May 2018 as follows. To physicians and pharmacists to find out their point of view as opinion leaders in the medical field. Specialized personnel who responded to our request are physicians (71) and pharmacists (6) with various medical and pharmaceutical specialties in the first year of doctoral studies at "Carol Davila" University of Medicine and Pharmacy, Bucharest, Romania, and pharmacists from the health system (20).

100 questionnaires were distributed, but only 97 of them could be used in the study.

To consumers/patients as users of food supplements. We obtained 99 responses of which 29 come from people who requested pharmaceutical services and 70 are responses obtained from first year students from the "Carol Davila" University of Medicine and Pharmacy, Faculty of Pharmacy, Bucharest, Romania. We considered that at this stage of university education, objectivity of responses is not affected by specialized knowledge gained.

The data set consisted of two subsets of nominal variables. The first subset contains the answers of the 97 medical professionals in the field of food supplements. Regarding the behaviour of individuals, in relation to the answers of the 5 questions from the questionnaire, there is a significant difference between the categories of response, $p<0.001$, except question 3 . About this question we could not demonstrate that the three kind of information sources are not equally attractive, $p=0.1068$. For this statistical analyse we used One-Sample Chi-Square Test.
From the total of 97 medical professionals, 26 are pharmacists and 71 are physicians. Between the two professional categories there was no significant differentiation in relation to the answers given to the 5 questions from the questionnaire, meaning the $\mathrm{p}$-value in each situation is much higher than the level of significance chosen of 0.05 . The statistical analysis was performed by using the Fisher's exact test, which has a higher accuracy, when the sample size is smaller for different sub-set of data.

Regarding the second dataset, there were obtained answers from 99 consumers/patients who complement the general picture of the individuals' behaviour relative to food supplements. Question number two from the questionnaire received multiple responses from the respondents which prompted us to consider it as a categorical variable with 5 variants of response that are consistent with the other variants of response: physician, pharmacist, both specialists, mixed sources, other sources. Regarding the individuals behaviour, in relation to the answers of the second questionnaire there are extremely significant differences between the response categories, $p<0.001$, except for question 5 from the questionnaire. About this question, we could not demonstrate that the occurrence of the side effect is not equally distributed after the consumption of food supplements, $p$-value $=0.1914$. For this statistical analyse, we performed the One-Sample Chi-Square Test.

In this final questionnaire for assessing the consumer feedback, a comparative analysis is required between couples of questions that could highlight a dependent relationship. We evaluated the behaviour of the variable that gives the confidence in food supplements related to the type of influence and also related to the fact that a medical prescription is not required. The result was that there was no association between them, $p$ > 
FARMACIA, 2019, Vol. 67, 4

0.05 . Also, if evaluating the association of the variable that measures expected results with encouraging the use of supplements in the absence of a prescription and also with the occurrence of adverse effects, no association was identified. In both cases, there is no association, the value $p>0.05$. Statistical testing was done by applying Fisher's exact test.

The last part of the statistical analysis followed the behaviour of individuals in the entire study related to the degree of confidence given to food supplements. Fisher's Exact Test for categorial data is $p<0.001$ which implies a significant difference between the two categories of individuals pursued in the study, consumers/patients on the one hand and medical professionals on the other.

Biostatistical analysis was implemented using the $\mathrm{R}$ statistical software ( $\mathrm{R}$ version 3.5.3).

Table II

Questionnaire 1 - the opinion of physicians / pharmacists about using food supplements 1. Do you consider that legal status and notification protocol certify the marketing of safe and effective food supplements?
a) Yes
b) No

2. Mention your level of confidence concerning food supplements:
a) very high
b) high
c) low
d) very low

3. This confidence is due to:

a) information received from the manufacturer by marketing service

b) "trials" made by the producer

c) an empirical assessment based on patient reports

4. Do you consider that are required clinical trials to certify the safety and effectiveness of these products?
a) Yes
b) No

5. Do you think that the release of food supplements without a prescription encourages the consumption?
a) Yes
b) No

Table III

Questionnaire 2 - the opinion of consumers/patients about using food supplements

1. Mention your level of confidence in food supplements:
a) very high
b) high
c) low
d) very low

2. Do you use food supplements due to information obtained from:
a) physician
b) pharmacist
c) other sources

3. The fact that it isn't necessary a medical prescription encourages your consumption of food supplements?
a) Yes
b) No

4. Did you obtain the expected results by using food supplements?
a) Yes
b) No

5. Did side effects occur after the consumption of food supplements?
a) Yes
b) No

\section{Results and Discussion}

The processing of responses led to the following results.

The degree of confidence in food supplements is as follows: for very high: physicians/pharmacists (86\%) and consumers/patients (14\%); for high: physicians/ pharmacists $(72 \%)$ and consumers/patients $(28 \%)$; for low: physicians/pharmacists (33\%) and consumers/ patients $(67 \%)$; for very low: physicians/pharmacists $(17 \%)$ and consumers/patients $(83 \%)$; p-value $<0.001$ (Figure 1).

For specialists, the sources that generated these degrees of confidence are: information provided by the manufacturer marketing service (41\%); empirical assessments based on patients' reports (24\%); clinical trials conducted by the manufacturer $(32 \%)$; $p$-value $=$ 0.1068 (Figure 2).

On the effectiveness and safety of food supplements: For physicians/pharmacists: only $27 \%$ deem them appropriate in terms of efficiency and safety (question 1 questionnaire 1), 98\% indicating the necessity of clinical trials to certify these qualities (question 4, questionnaire 1), p-value $<0.001$ (Figure 3).

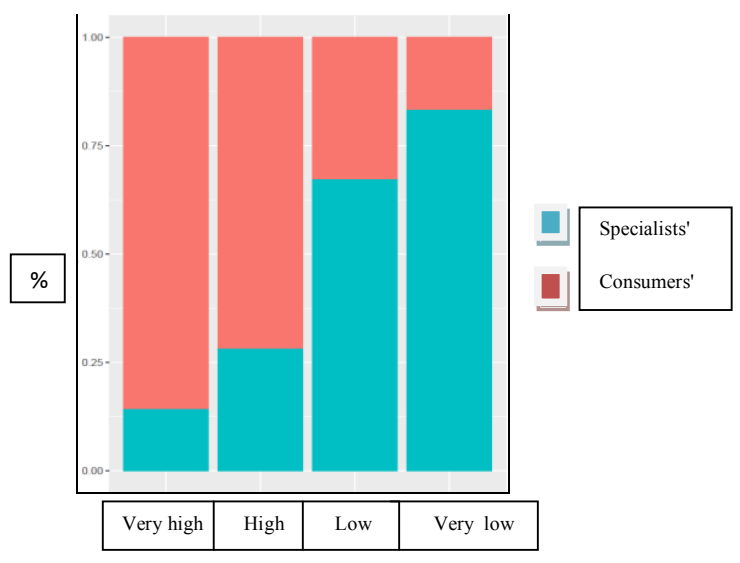

Figure 1.

The degree of confidence in food supplements specialists' (question 2, questionnaire 1) and consumers'/patients' answers (question 1 questionnaire 2) 


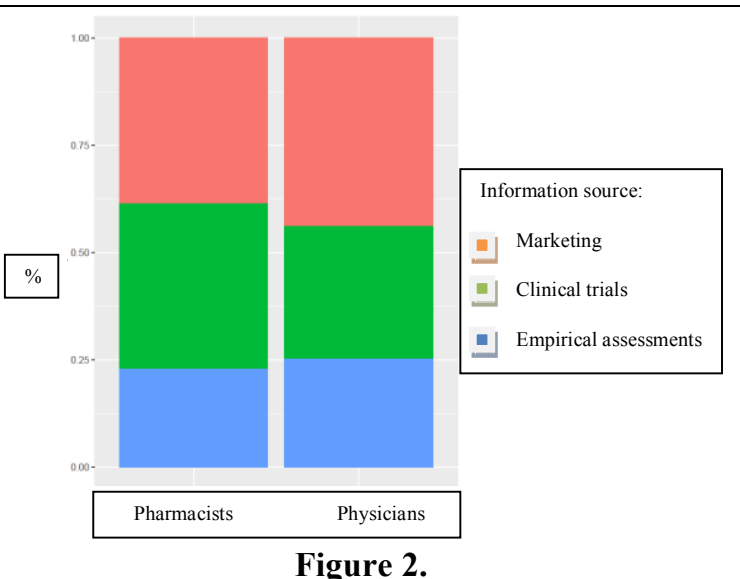

Specialists' explanation about the source that generated the level of confidence in food supplements (question 3, questionnaire 1)

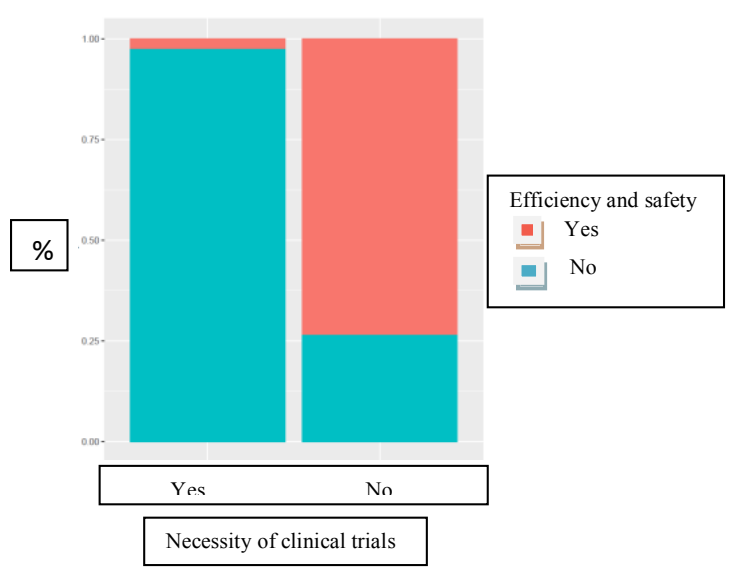

Figure 3.

Specialists' answers about efficiency and safety (question 1 questionnaire 1) or necessity of clinical trials (question 4, questionnaire 1)

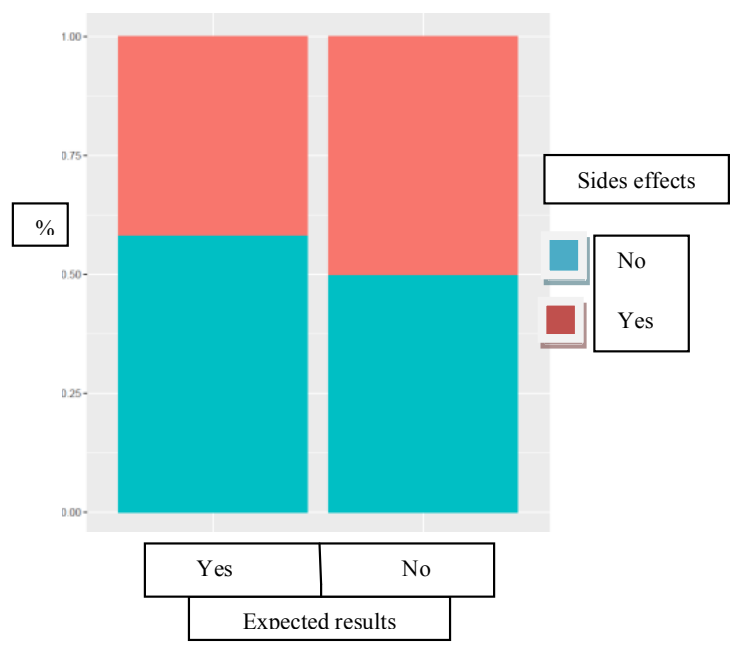

Figure 4.

Consumers' answers about obtaining of expected results (question 4, questionnaire 2) or side effects (question 5, questionnaire 2)
For consumers/patients: $79 \%$ consider that the expected results were obtained by using food supplements (question 4, questionnaire 2) and $43 \%$ asserts that after the consumption of these products sides effects occur (question 5, questionnaire 2); p-value $=0.6813$ (Figure 4).

Regarding the role of specialists in informing consumers/ patients about food supplements, $18 \%$ of the respondents stated that they were informed by physicians, $29 \%$ by pharmacists and $33 \%$ obtained information from other sources, physician's advice associated with the pharmacist's one (5\%), mixed (15\%); p-value $<0.001$ (Figure 5).

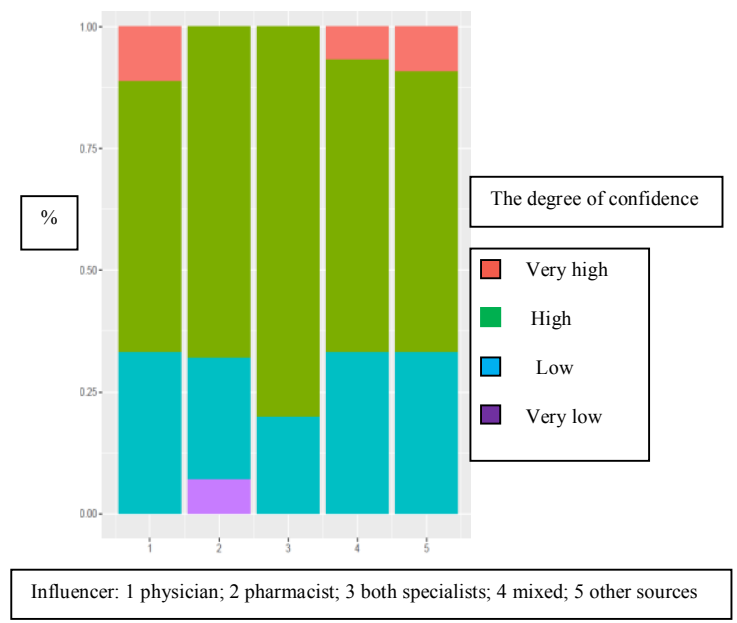

Figure 5.

The degree of confidence in relation to the influencer (question 2, questionnaire 2)

On the relation between the consumption of food supplements and the fact that these can be bought without a prescription, most respondents from both categories $-96 \%$ (p-value $<0.001)$ of specialists and $84 \%$ of consumers/patients ( $p$-value $<0.001$ ) considered that so is being favoured the consumption of these products.

As in our study, surveys performed in other countries have reported a significant and increasing use of dietary supplements in recent years. In the U.S. studies have showed that dietary supplements are used by the majority of the population [2, 3, 11]. The insufficient intake of some vitamins and minerals reported by many studies and national guidelines represent a national factor that can contribute to the increased use of supplements by the general public. A study revealed that also physicians and nurses from U.S. are likely to use dietary supplements, $79 \%$ of physicians and $82 \%$ of nurses recommending them to their patients [6]. Another study offered the same conclusion: $62 \%$ of cardiologists, $66 \%$ of dermatologists and $91 \%$ of orthopaedists (from 900 physicians participating to the survey) were in favour with the use of supplements [7]. A study from Serbia has showed that $88.9 \%$ from all the 
FARMACIA, 2019, Vol. 67, 4

subjects to the questionnaire did not inform their physician or pharmacist about use of herbal dietary supplements, meaning the information comes from unspecialized sources, the same as the situation encountered in Romania [13]. Data from a study performed in Japan also indicated that almost $70 \%$ from all participants did not mention dietary supplement use to their physicians and $3.3 \%$ realized adverse effects associated with dietary supplements [4]. Aspects about adverse effects [4, 8], unspecialized sources of information $[4,12,13]$, increasing of consumption due to lack of recipe at release have been treated in these articles [11].

\section{Conclusions}

Physicians and pharmacists acknowledge a low (62\%) and very low degree of confidence $(10 \%)$. It is noted that marketing services (41\%) and "clinical trials" made by manufacturers (32\%) failed to persuade in a greater extent. This distrust of specialists is generated by the belief that judicial regime and notification protocol do not certify the marketing of safe and effective $(73 \%)$ products, so they consider necessary to performed clinical trials $(98 \%)$.

Unlike specialists, consumers/patients show a high $(61 \%)$ and very high $(6 \%)$ degree of confidence for food supplements. This may be due to the fact that information about these products comes in fairly large proportion $(33 \%)$ from other sources than the specialized ones (medical and pharmaceutical). Despite that confidence, $43 \%$ of the consumers/patients reported side effects to the use of food supplements therefore it is necessary to deepen the studies by which is verified the authenticity of this opinion.

Uncontrolled releases, without requiring a prescription, encourage the consumption of food supplements. This is the opinion of specialists (93\%) and the consumers'/ patients' $(83 \%)$ too.

\section{Acknowledgement}

This paper was financially supported by "Carol Davila" University of Medicine and Pharmacy through Contract no. CNFIS-FDI-2019-0534 (MEDEX-II) funded by the Ministry of National Education of Romania, from the Institutional Development Fund for Public Universities - FDI 2019.

\section{References}

1. Anadón A, Martínez-Larrañaga MR, Ares I, Martínez MA, Evaluation and Regulation of Food Supplements: European Perspective, Nutraceuticals, 2016; 63: 895923. https://books.google.ro/books.

2. Bailey RL, Gahche JJ, Miller PE, Thomas PR, Dwyer JT, Why US Adults Use Dietary Supplements. JAMA Intern Med., 2013; 173(5): 355-361.

3. Bailey RL, Gahche JJ, Lentino CV, Dwyer JT, Engel JS, Thomas PR, Betz JM, Sempos CT, Picciano MF,
Dietary Supplement Use in the United States, 20032006. J Nutrition, 2011; 141(2): 261-266.

4. Chiba T, Sato Y, Nakanishi T, Yokotani K, Suzuki S, Umegaki K, Inappropriate Usage of Dietary Supplements in Patients by Miscommunication with Physicians in Japan. Nutrients, 2014; 6(12): 5392-5404.

5. Crișan $\mathrm{O}$, Health claims in food supplement advertising. Farmacia, 2012; 60(1): 138-143.

6. Dickinson A, Boyon N, Shao A, Physicians and nurses use and recommend dietary supplements: report of a survey, Nutrition J., 2009; 8: 29.

7. Dickinson A, Shao A, Boyon N, Franco JC, Use of dietary supplements by cardiologists, dermatologists and orthopedists: report of a survey. Nutrition J., 2011; 10: 20.

8. Dumitru Croitoru M, Fülöp I, Zaharia M, Modroiu A, Zecheru L, Fogarasi E, Presence of declared and undeclared caffeine and ephedrine in weight-loss herbal supplements. Farmacia, 2017, 65(6): 968-971.

9. Dweyer JT, Coatas PM, Smith MJ, Dietary Supplements: Regulatory Challenges and Research Resources. Nutrients, 2018; 10(1): 41.

10. Florea M, Monciu CM, Ilie M, Resonance Rayleigh scattering study of streptomycin - Congo red ionic association in view of analytical application. Farmacia, 2014; 62(2): 318-328.

11. Qato DM, Wilder J, Schumm LP, Gillet V, Alexander GC, Changes in Prescription and Over-the-Counter Medication and Dietary Supplement Use Among Older Adults in the United States, 2005 vs 2011. JAMA Intern Med., 2016; 176(4): 473-482.

12. Rusu A, Vari CE, Hancu G, Pasca MD, Botezatu R, Cucoranu D, Muntean DL, Brief assessment of pharmacist-patient communication efficiency in Romanian pharmacies. Farmacia, 2018; 66(6): 1091-1096.

13. Samojlik I, Mijatović V, Gavarić N, Krstin S, Božin $\mathrm{B}$, Consumers' attitude towards the use and safety of herbal medicines and herbal dietary supplements in Serbia. Int J Clin Pharm., 2013; 35(5): 835-840.

14. Stancu E, Carata A, Soroceanu V, Tăerel AE, The study Pharmacopoeias used in Romanian area in XVIII-XX ${ }^{\text {th }}$ century: evolution of proportions for drug substances and pharmaceutical preparations. Farmacia, 2014; 62(5): 1037-1048.

15. Stancu E, Carata A, Tăerel AE, From the history of drugs: Oleum Jecoris, a long time used remedy. Farmacia, 2015; 63(5): 776-780.

16. Tăerel AE, Soroceanu V, Rais C, Stancu E, Study of quality standards application in Bucharest community pharmacies. Farmacia, 2014; 62(6): 1082-1088.

17. $\mathrm{xxx}$ - Caracteristics and perspectives of the market for food supplements containing substances other than vitamins and minerals. https//ec.europa.eu/food/files/ safety/docs/labelling_nutrition-supplements-2008 2976_f_wd1_en.pdf

18. xxx - Directive 2002/83/EC of the European Parliament and of the Council of 6 November 2001 on the Community code relating to medicinal products for human use. http://eurlex.europa.eu/LexUriServ/LexUri Serv.do?uri=CONSLEG:2001L0083:20070126:en:PDF

19. xxx - Directive 2002/46/EC of the European Parliament and of Council of 10 June 2002 on the approximation of the laws of the Member States relating to food 
supplements. http://eurlex.europa.eu/LexUriServ/Lex UriServ.do?uri=OJ:L:2002:183:0051:0057:En:PDF

20. xxx - Directive 2002/24/EC of the European Parliament and of the Council of 31 March 2004 amending, as regards traditional herbal medicinal products. http://eurlex.europa.eu/LexUriServ/LexUriServ.do?uri= OJ:L: 2004:136:0085:0090:en:PDF

21. xxx - Directive 2004/27/EC of the European Parliament and of the Council 31 March 2004 amending Directive 2001/83/EC on the Community code relating to medicinal products for human use. http://ec.europa.eu/ health/files/eudralex/vol-1/dir_2004_27_en. pdf

22. xxx - European Food Safety Authority. Dietary Reference Values for nutrients. Summary Report. www.efsa. Europa.eu/sites/default/files/2017_09_DRVs_sum mary_report.pdf.

23. xxx - European Food Safety Authority. Food supplements. www.efsa.europa.eu/topics/food-suppl.

24. xxx - Order 244/2005 of the Minister of Agriculture, Forests and Rural Development and the Minister of Health on the processing and marketing of medicinal and aromatic plants used as such, partially processed or processed in the form of pre-enriched food supplements, Official Journal of Romania, Part I, no. 456/May 2005, (available in Romanian).

25. xxx - Order 63/2006 of the Minister of Health, the Minister of Agriculture, Forests and Rural Development and the President of the National Sanitary Veterinary and Food Safety Authority for the approval of the
Technical Norms on the marketing of pre diluted food and animal food supplements and/or their mixtures with vitamins, minerals and other nutrients, Official Journal of Romania, Part I, no. 253 of March 21, 2006, (available in Romanian).

26. xxx - Order of the Ministry of Health no.1069 of June 19, 2007 for the approval of the rules on food supplements, Official Journal of Romania, Part I, no. 455 of July 5, 2007, (available in Romanian).

27. $\mathrm{xxx}$ - Report from the Commission to the Council and the European Parliament on the substances other than vitamins and minerals in food supplements, Brussels, 12.2008. www.ehpm.org/Foods-SupplementDirective

28. $\mathrm{xxx}$ - The use of substances with nutritional or physiological effects other than vitamins and minerals in food supplements - Study undertaken for DG Sanco, European Commission, 28 March 2007. http://ec.europa.eu/food/food/labellingnutrition/sup pliments/documents/2007_A540169_study_other_s ubstances.pdf

29. xxx - World Health Organization - Traditional Medicine Strategy: 2014-2023. www.who.int/medicines/ publications/traditional/trm_strategy14_23/en/

30. xxx - World Health Organization - National Policy on Traditional Medicine and Regulation of Herbal Medicines. Report of a WHO Global Survey. http://apps. who.int/medicinedocs/en/d/Js7916e/ 